\title{
Integration of extreme weather event risk assessment into spatial planning of electric power infrastructure
}

This article examines practical measures for integrating risk assessment of extreme weather events into spatial planning. An approach that integrates risks due to ice storms into spatial suitability analysis is presented in two case studies: in siting transmission and distribution power lines, and in siting windfarms. Assessment of risks to the power grid due to ice storms is carried out first. The results of the risk assessment are then used as a basis for analysing proposed alternatives for siting high-voltage power lines and as input in analysing the suitability of space for siting windfarms. The results of a cost-benefit analysis of various alternatives for siting windfarms (an alternative that takes risks due to ice storms into account and one that does not) show that the damage caused by extreme weather events has a significant impact on the economic viability of a plan. There are two options for integrating risk assessment results into planning electric energy infrastructure: by updating engineering standards and by avoiding areas where greater damage to infrastructure due to extreme weather events is expected. Risk assessment provides important information that can affect decisions about land use and decisions about technical measures for enhancing the physical resilience of infrastructure.

Keywords: spatial planning, risk assessment, extreme weather events, energy infrastructure, vulnerability 


\section{Introduction}

Gradual climate change with rising mean temperatures and changed precipitation patterns is expected to impact electricity supply and demand as well as its price, accessibility and transmission or distribution (Feeley et al., 2008; Wilbanks et al., 2008; Kopytko \& Perkins, 2011; Rübbelke \& Vögele, 2011; McColl et al., 2012; Schaeffer et al., 2012). Extreme weather events (EWE) such as strong wind, heavy rainfall or snow, ice storms, hail and so on or various combinations of these extreme conditions may cause damage to hydroelectric power plants, coal-fired power plants, nuclear power plants, wind turbines, solar panels, power lines and substations (Auld et al., 2006; McColl et al., 2012; Schaeffer et al., 2012; International Atomic Energy Agency (IAEA), 2013; Patt et al., 2013; Sieber, 2013). According to the Intergovernmental Panel on Climate Change (IPCC; 2012, 2013), both the intensity of EWE and the frequency of EWE with specific intensities have recently increased, and this trend is expected to continue in the future. Energy infrastructure has a long lifespan and decisions about its location and technical implementation made now will have long-term consequences. This is why gradual climate change and EWE should be taken into account in the planning process, which demands an analysis of various adjustments and adaptation measures (Auld et al., 2006; Wilbanks et al., 2008; Rübbelke \& Vögele, 2011; Schaeffer et al., 2012; IAEA, 2013). Building energy infrastructure that is resilient to gradual climate change and EWE is one of the key adaptation measures of the energy sector (Auld et al., 2006; Cortekar \& Groth, 2015; Panteli \& Mancarella, 2015), which is also pointed out in international and national policies such as the United Nations Framework Convention on Climate Change (2014), the EU Strategy on Adaptation to Climate Change (European Commission, 2013) and the US Draft Climate Change Adaptation Plan (United States Environmental Protection Agency (EPA), 2012a). The Slovenian draft national energy programme (see Jožef Stefan Institute, 2011) listed "reliable energy service in extreme conditions, such as natural disasters" among the goals for reliability of the energy supply. The draft national energy programme prepared in 2011 was not adopted and therefore not implemented. The decision-making process about the draft national energy programme was stopped after public discussion and transboundary impact assessment, and the document remained at the draft level. The energy sector development document still in force is the Resolution on the National Energy Programme (Sln. Resolucija o Nacionalnem energetskem programu, Ur. l. RS, no. 57/2004), which was adopted in 2004. It will be replaced by the Energy Concept of Slovenia (Sln. Energetski koncept Slovenije), which is being prepared. The Proposal for Guidelines for Preparing the Energy Concept (Sln. Predlog usmeritev za pripravo Energetskega koncepta, Ministry of Infrastructure of the Republic of Slovenia, 2015) lists a reliable energy supply among the goals for a sustainable energy sector. This goal should be attained via development of a reliable power grid and the use of dispersed energy sources. The resilience of infrastructure to EWE is not explicitly mentioned.

There are, in general, two approaches to preventing damage to power infrastructure: 1) technical (mechanical) improvement of the components, making them more robust and resistant to physical stress, and 2) considering the physical location of infrastructure and locating it to places where its vulnerability to gradual climate change and EWE is lower (Auld et al., 2006; IAEA, 2013). Operationally, the second option is related to spatial planning. Planning land use that takes into account risks due to various factors is more cost-effective than structural measures for risk reduction (Sudmeier-Rieux et al., 2015). Studies on integrating risk assessment into spatial planning (ARMONIA; Lancaster University, 2007; Sutanta et al., 2010; Storch \& Downes, 2013; Prawiranegara, 2014) have concentrated on developing a decision-support system and not specifically on the use of risk-assessment results for allocating new facilities. We focus on this particular issue with the aim of filling the gap by showing how existing approaches in land-use planning can be adjusted to take into account the results of risk assessment of gradual climate change and EWE.

The research background and connected hypothesis is as follows: it is rational and feasible to integrate risk assessment into spatial planning in order to reduce damage to energy infrastructure caused by EWE. The article starts by presenting the importance of spatial planning in reducing risks posed by gradual climate change and EWE and the use of risk assessment in spatial planning. These two fields are then connected by developing a method for integrating them. The use of the method is presented in a case study on risks to energy infrastructure due to ice storms in Slovenia. In the case study, risk assessment is used to support analysis of proposed alternatives of a planned high-voltage power line and for determining the most suitable locations for siting windfarms. This is followed by a cost-benefit analysis of three development alternatives: one that takes risks due to ice storms into account by siting windfarms (no wind turbines are located in areas with high risk); one that includes technical measures for damage prevention or reduction in areas with high risk; and one in which risks are not considered. The presentation of the results is followed by a discussion of the usefulness of the proposed approach and its strengths and weaknesses. The conclusion proposes directions for further research. 


\section{Theoretical background}

\subsection{The role of spatial planning in adapting to gradual climate change and extreme weather events}

Spatial planning has been recognised as a basis for adaptation to climate change in research literature (Biesbroek et al., 2009; Wilson \& Piper, 2010; Hurlimann \& March, 2012; Rastandeh, 2015) and in several strategic documents; for example, the Green and White Paper of the European Commission (European Commission, 2007, 2009) and the Territorial Agenda of the European Union (European Commission, 2011). In Slovenia too, spatial planning has explicitly been pointed out as a priority of adaptation because it offers important preventive instruments for adapting to climate change through integrated planning and urban development (Government Office of the Republic of Slovenia for Climate Change, 2011; Kajfež-Bogataj et al., 2012). A great number of studies about the effectiveness of spatial planning in climate change adaptation have been carried out at the international level (e.g., International Commission for the Protection of the Alps, 2010; Pütz et al., 2011; Linkaits, 2013), as well as at the national level (e.g., Rivera \& Wamsler, 2014; Flannery et al., 2015; Kumar \& Geneletti, 2015), regional level (e.g., Rannow et al., 2010; De Bruin et al., 2013) and local level (e.g., Wilson, 2006; Andersson-Sköld et al., 2015; Dubois et al., 2015). In Slovenia, spatial planning as a tool for adapting to climate change was analysed by Mojca Golobič et al. (2012). The authors of these studies state that spatial planning is an activity with the ability to help society and the economy with adaptation to landuse change, prevention of natural disasters and integration of various fields into planning (Rannow et al., 2010; Pütz et al., 2011; Greiving \& Fleischhauer, 2012; Serrao-Neumann et al., 2015). They point out that some spatial-planning instruments already include measures for adapting to climate change but these measures are not sufficient or are not suitably implemented in order to transfer adaptation into practice (Wilson, 2006; Rannow et al., 2010; Golobič et al., 2012, Pütz et al., 2011). The same authors conclude that it is necessary to make a step from the strategic level towards consistent implementation of adaptation by means of spatial planning at the operational level. Sven Rannow et al. (2010) argue that assessment and use of data about the frequency and intensity of extreme events are limiting factors for spatial planners and they propose using findings of other disciplines in order to take EWE into account. In spatial planning legislation, climate change is addressed implicitly - as a part of protection or restoration of the natural environment, protection of settlements against natural disasters, and environmentally and economically suitable spatial development (Government Office of the Republic of Slovenia for Climate Change, 2011).

\subsection{Risk assessment and integrating it into spatial planning}

A great number of studies about risks due to natural and/ or anthropogenic extreme events have been carried out in the past two decades. Many of these studies were carried out with the support of international organisations, such as Nato (Briggs et al., 2002), the European Union (the research projects Accidental Risk Assessment Methodology for Industries, or ARAMIS, 2002-2005; Sharing Experience on Risk Management (Health, Safety and Environment) to Design Future Industrial Systems, or SHAPE-RISK, 2004-2007; ARMONIA, 2004-2007; Early Recognition, Monitoring and Integrated Management of Emerging, New Technology Related Risks, or iNTeg-Risk, 2008-2013; Technology Opportunities and Strategies Towards Climate-Friendly Transport, or TOSCA, 2010-2013; Coordination of European Research on Industrial Safety towards Smart and Sustainable Growth, or SAFERA, 2012-2015), the United Nations Office for Disaster Risk Reduction (UNISDR) and the International Atomic Energy Agency (CRP Techno-Economic Evaluation of Options for Adapting Nuclear and Other Energy Infrastructure to Long-Term Climate Change and Extreme Weather, 2012-2015). The body of scientific literature about risk assessment is also extensive; it studies risks due to various extreme events; for example, erosion (Alder et al., 2015), floods (Camarasa-Belmonte \& Soriano-García, 2012; Zhou et al., 2012; Canters et al., 2014; Prawiranegara, 2014; Foudi et al., 2015), forest fires (Thompson et al., 2015) and others. These studies place great emphasis on developing methods to reduce the consequences of various types of extreme events. Melanie Gall et al. (2015) studied interdisciplinary research on risks in the past fifteen years that connected various research fields, methods and stakeholders. They conclude that there is a large gap between research and implementation in practice. Even though most of the these articles stress that the riskassessment methods they have developed and presented may be used as decision support and could be included in spatial planning (e.g., Camarasa-Belmonte \& Soriano-García, 2012; Alder et al., 2015; Foudi et al., 2015; Thompson et al., 2015), this integration is not further explored. Most studies that address integrating risk assessment into spatial planning (Lancaster University, 2007; Sutanta et al., 2010; Storch \& Downes, 2013; Prawiranegara, 2014) focus on designing decision support systems based on maps of integrated hazards or risks and not on developing methods for finding suitable locations for specific activities, uses or facilities. Marisa Berry and Todd BenDor (2015) included projections of sea level rise and inundated areas due to storm surges into spatial suitability analysis, but this mostly means siting activities away from the coast and lower lying areas; their study takes into account neither the 
probability of occurrence of storms nor their consequences. Stefan Greiving et al. (2006) believe that risk assessments carried out by professionals from various fields are not ready to be used in spatial planning; transfer of information about risks into the language of spatial planning is needed in order to use this information in the planning process. This problem was addressed by Davor and Branko Kontić (2008) in a case study of risks due to industrial accidents. The approach presented in this article builds on and further develops their method by focusing on risks due to extreme natural events. We presume that integrating gradual climate change and EWE into the spatial planning of energy infrastructure would optimise their efficiency and prevent or decrease possible damage. This article presents an approach for choosing suitable locations for siting energy infrastructure that was developed and tested in a case study of risk to energy infrastructure due to ice storms in Slovenia.

\section{Methods}

The method integrating risk-assessment results into spatial planning is based on the approach developed in a case study of risks due to industrial accidents by Kontić and Kontić (2008). By using spatial planning tools, they tried to prevent or minimise the consequences of industrial accidents in the vicinity of organisations in the category of higher risks according to Council Directive 96/82/EC of 9 December 1996 on the control of major accident hazards involving dangerous substances (Seveso II Directive, Official Journal of the EU, no. 10/1997). We further developed their approach and adapted it for risk assessment of extreme events as consequences of natural processes with a focus on risk due to EWE. The terminology used in this article has different meanings in different contexts or fields. In risk assessment the terms risk, hazard and vulnerability are defined as follows:

- A risk is the likelihood of occurrence (expressed in frequency or probability) of specific consequences as a result of exposure to a specific stressor or hazard (EPA, 2012b; UNISDR, 2014);

- A hazard is a dangerous phenomenon, substance or activity that may cause adverse consequences (loss of life, injury or other health impacts, property damage, loss of livelihoods and services, social and economic disruption or environmental damage) in a system exposed to the hazard (UNISDR, 2014);

- The vulnerability of a system (e.g., energy infrastructure, forest, etc.) is the characteristics and circumstances of a community, system or asset that make it susceptible to the damaging effects of a hazard; possibility that the exposed subject or system may be affected by the phenomenon in case of exposure (Cardona, 2003; UNISDR, 2014); the purpose of determining the vulnerability of a system is to reduce risk by using technical measures or adjustment of existing land use.

The IPCC (2007) provides a different definition of vulnerability to climate change. Vulnerability is assumed to be the result of three factors: 1) a function of the character, magnitude and rate of change that a system is exposed to, 2) the sensitivity of a system and 3) its adaptive capability. Each of these factors is assessed based on criteria and indicators that can be described with qualitative or quantitative data. Spatial or environmental vulnerability is a term used in spatial planning defining potential negative effects that the proposed development plan may have on individual environmental components and the environment as a whole at a specific location. This article uses two terms: vulnerability of a system as defined in risk assessment and spatial or environmental vulnerability as defined in spatial planning.

\subsection{Method for assessing risk to energy infrastructure due to extreme weather events}

The method for assessing risk to energy infrastructure due to extreme weather events was tested in a case study of risk to energy infrastructure posed by ice storms. The method comprises four steps:

1. Determining the geographic scope and intensity level of an extreme weather event based on data from past occurrences. The intensity level of each EWE (e.g., mass, force, temperature, burden due to glaze ice, strong wind, heavy snow, heavy rain storm, etc.) is represented on GIS-based maps (see Figure 1), in which each cell is evaluated on a scale from 1 (low) to 4 (high) for physical burden on the electric energy infrastructure. The size of the cell depends on the size of the area analysed and the detail of the analysis. In the analysis presented here, which was carried out at the level of all of Slovenia, the cell measured $100 \mathrm{~m} \times 100 \mathrm{~m}$. The data were obtained from archives about past EWE. We used data about locations of damaged power lines and elevation above sea level where the damage was present. The events were categorised into classes of intensity based on financial damage caused by a specific event. The thresholds of these categories were determined according to the amount of financial means allocated by transmission and distribution companies for infrastructure maintenance.

2. Analysis of the vulnerability of the electric energy infrastructure and the location and the environment in which the infrastructure is situated to a specific EWE. The purpose of this step is to determine whether the energy infrastructure at a specific location is able to withstand an 


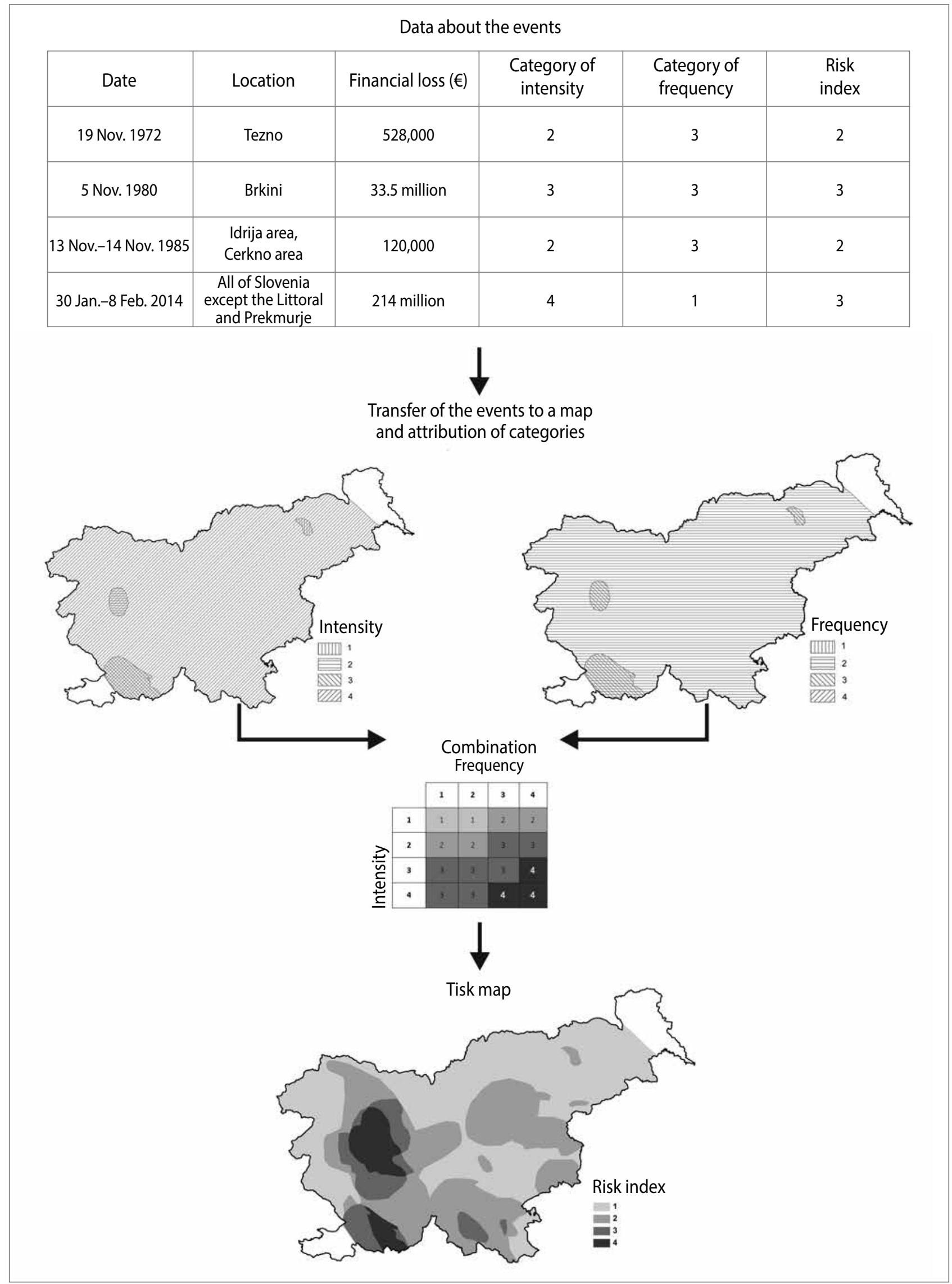

Figure 1: Risk assessment steps (illustration: Maruša Matko). 
EWE of a given intensity level. A particular EWE can cause direct, primary damage to energy infrastructure as well as secondary damage due to environmental damage (e.g., falling trees or erosion), which causes additional structural and other damage and loss to the energy infrastructure. The vulnerability of infrastructure, in terms of primary damage, can be specified and evaluated by using construction and other engineering or quality standards, whereas vulnerability due to destruction of environmental features (i.e., secondary damage) is more complex and is affected by several factors. In the case of glaze ice, damage to forests has been used as a determinant or indicator of environment-related vulnerability. Vulnerability is expressed as the ratio of the expected level of damage or loss of the infrastructure to the maximum possible damage or loss and is expressed on a scale of 1 to 4 . The results are represented on GIS-based maps for various EWE at specific locations (see Figure 1).

3. Assessment of the probability or frequency of occurrence of an extreme weather event at a particular site or region where specific energy infrastructure is, or will be, located. Based on historical data about EWE, the frequency or probability of occurrence of various types of EWE is calculated. The results are presented on maps.

4. Integration of the three steps above, with the aim of determining physical and other (e.g., economic or health) consequences that will lead to the specification of a risk index pertaining to the particular area and infrastructure. The risk index integrates the intensity of an EWE and the vulnerability of energy infrastructure to the specific intensity level of an EWE, the frequency or probability of occurrence of an EWE and consequences; that is, social damage due to damaged infrastructure. These combinations are similar to the standard risk matrices used for integrating the frequency or intensity of events with the consequences of these events.

Practical implementation of risk assessment of the four selected icing events and the damage caused by them is presented in Figure 1. First, data about the occurrences of ice storms, their locations and the damage they caused were obtained. Each event was then drawn on a map in a GIS environment (see Figure 1) and categorised into a class of intensity based on the damage it caused (which depends on intensity of the event and vulnerability of a system). Each event was categorised into a class of frequency of occurrence. In Figure 1, hatching (line fill) is used to represent the intensity and frequency of selected events in order to show the spatial distribution of events, which has impact on the final result. Only four selected events are presented on intensity and frequency maps to facilitate readability; see the paper by Maruša Matko et al. (2015) for data about all the events. By integrating the categories of intensity and frequency of the events, we obtained a risk index for each event, and risk indices of all the events were then combined into the end result, a risk map. The risk map in Figure 1 takes into account all of the icing events that were considered.

Assessment of risks to electric power lines due to ice storms was carried out using data on the occurrence of damage to forests and electric infrastructure. This is based on data on the occurrence of ice storms between 1961 and 2014 collected by the Slovenian Environment Agency (ARSO) and reports about damage caused by glaze ice (Šifrer, 1977; Radinja, 1983; Kern \& Zadnik, 1987; Papler, 1996; Bogataj, 1997; Jakša, 1997; Jakše, 1997; Kastelec, 1997; Lapajne, 1997; Nadižar \& Papler, 1997; Šipec, 1997; Trontelj, 1997a; Trontelj, 1997b; Zadnik, 1997; Špehar, 1998; Rebula, 2001; Rebula, 2002; Zadnik, 2006; Habjan \& Bahun, 2009; Habjan, 2010; Sinjur et al., 2010; Bahun, 2014; Bahun et al., 2014; Belak \& Maruša, 2014; Belak et al., 2014; Jakomin, 2014; Zavod za gozdove Slovenije, 2014 and Elektro Slovenija, 2015), data about the basic characteristics of a specific event (location affected, damage to forests, size of the area where damage occurred and volume of damaged wood biomass) and damage to the transmission and distribution network (length of damaged power lines, number of damaged columns and financial damage as a consequence of physical damage and number of customers that suffered power loss). Financial damage to the power infrastructure was calculated according to the average prices of components of the power grid from Key F (average price in the electric power network grouped by activities; Sln. Šifrant $F$ - povprečna cena po skupinah del v elektroenergetskem omrežju, Administration of the Republic of Slovenia for Civil Protection and Disaster Relief, 2014) used for calculating damage caused by the 2014 ice storm. Financial damage to forests was calculated from data on physical damage to forests, using the average price of wood biomass in Slovenia over the last decade, which amounts to about EUR $50 / \mathrm{m}^{3}$ (Statistical Office of the Republic of Slovenia, 2015). Damage to forests was addressed separately from that to power lines; risk assessment was carried out and a risk map was prepared for each sector separately and then aggregated to yield the final result. Based on physical damage to forests and to the electric infrastructure leading to financial damage, the events were categorised into classes from 1 to 4 (in which class 1 represents the lowest and 4 the highest intensity level of ice storm). The frequency of occurrence of each event in the observation period (19612015) was calculated. Based on the frequency of occurrence, events were then categorised into classes from 1 (very low frequency) to 4 (very high frequency). These were then combined with the consequence categories using a matrix and the result was the categorisation of each event into a class of risk index ( $1=$ lowest risk, $4=$ highest risk). The events arranged based on the risk index were then drawn on a map, and the end result is the risk map presented in Figure 2. 


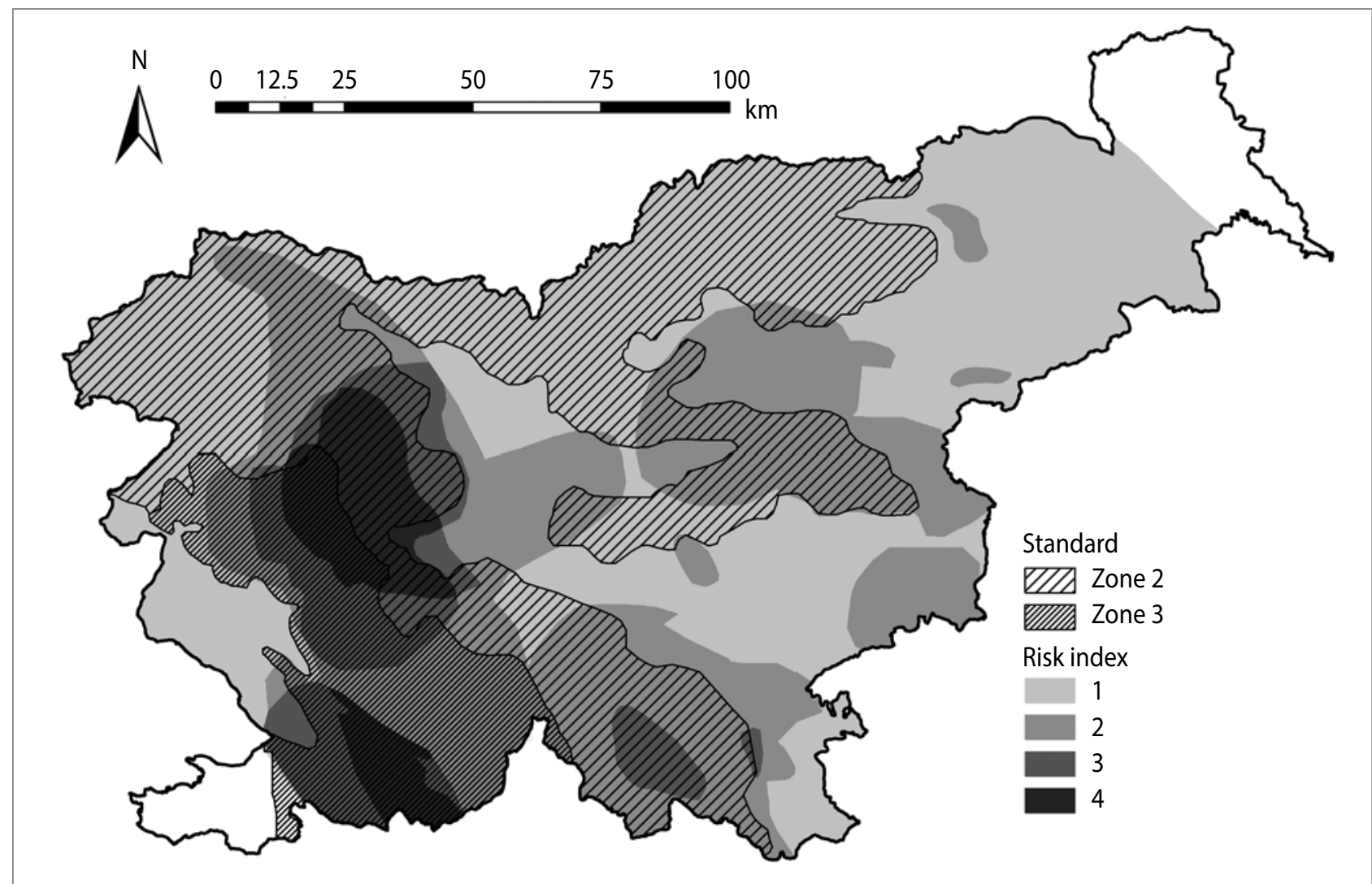

Figure 2: Map of risks to electric energy infrastructure due to ice storms overlaid with standard SIST EN 50341-3-21 for building high-voltage overhead lines (illustration: Maruša Matko).

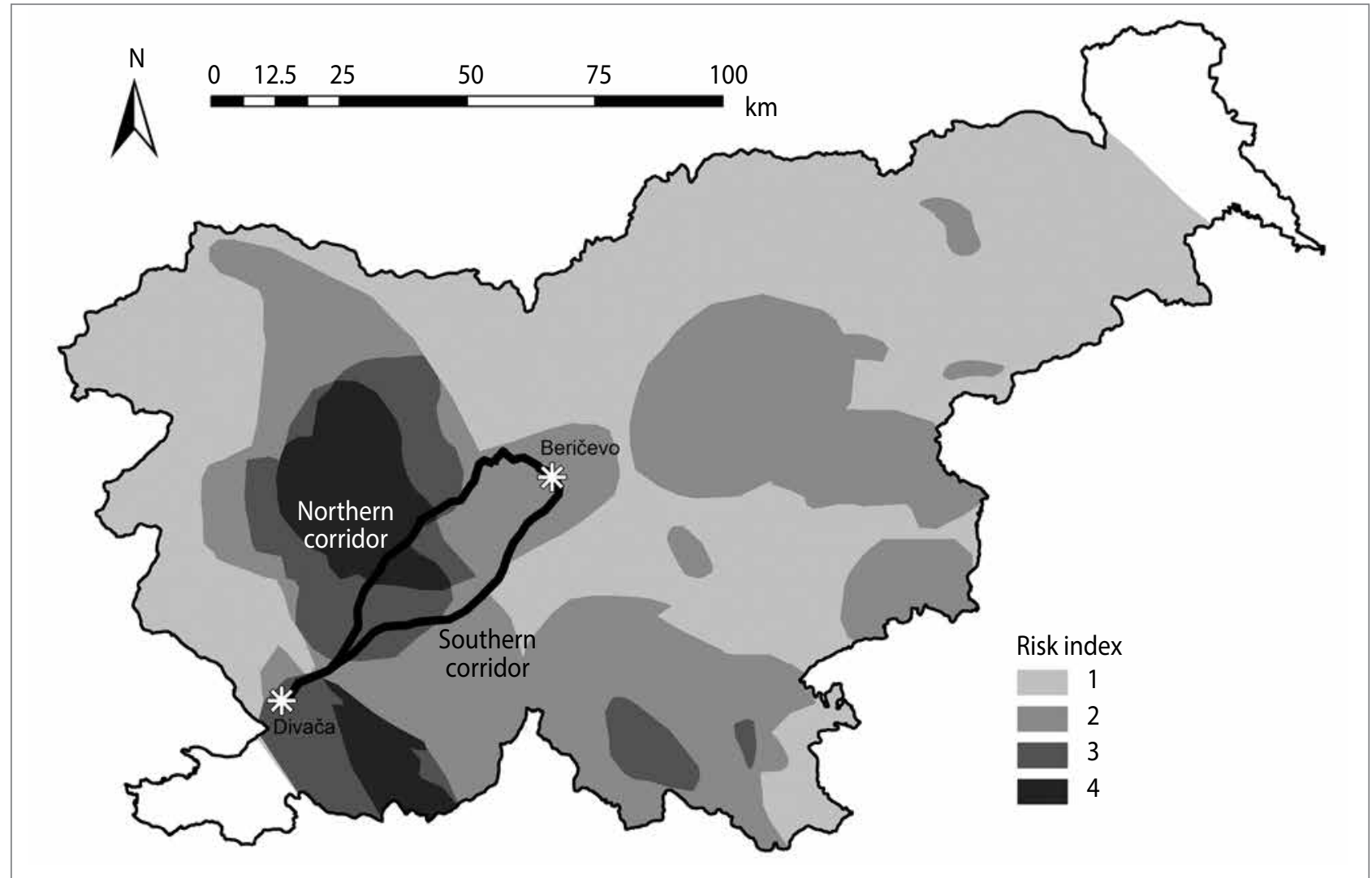

Figure 3: Map of risks to electric energy infrastructure due to ice storms and proposed alternatives of the $400 \mathrm{kV}$ Beričevo-Divača power line (illustration: Maruša Matko). 


\subsection{Method for integrating the results of risk assessment into a spatial suitability analysis for a specific activity}

A spatial suitability analysis for wind farm siting in Slovenia was carried out first. In Slovenia, analysis of suitability of space for a specific activity has been in practice since the early 1990s. It consists of two components: analysis of spatial attractiveness for a specific activity and analysis of vulnerability of the environment to this activity. The analysis of spatial attractiveness evaluates the characteristics of an area in the context of technical and economic feasibility or attractiveness for the proposed development project. Analysis of environmental vulnerability, on the other hand, determines how vulnerable the same area is to this activity and serves as an early warning system to avoid excessive environmental impacts in the area where the project is to be implemented. The synthesis of spatial attractiveness and environmental vulnerability analysis is optimised by means of a suitability matrix into a spatial suitability model. The overall process is GIS-supported. The suitability analysis method and process are not described in detail because they followed standard approaches (Marušič, 1993; Marušič et al., 1993; Koblar et al., 1997; Marušič et al., 2004). The criteria taken into account in the analysis of spatial attractiveness for siting wind farms are: wind conditions (average annual wind speed according to the AIOLOS and Aladin, or DADA, models; areas with a wind speed of $5 \mathrm{~m} / \mathrm{s}$ or more are the most attractive), land cover as a factor contributing to roughness of surface, the vicinity of a highvoltage electric power grid (power lines and substations), accessibility or the vicinity of roads, slope, geologic material, soil stability, the presence of water erosion and areas subjected to flooding. In the environmental vulnerability model, we took into account wildlife corridors, bear habitats, data on bird habitats prepared by DOPPS (Birdlife Slovenia), ecologically important areas, Natura 2000 sites protected under both the Birds Directive and the Habitats Directive, natural protected areas, the human living environment (settlements, tourist attractions, cultural heritage and water source protection areas), visual qualities (exceptional landscapes, areas under complex protection of cultural heritage and protected areas, especially visually exposed areas visible from frequently visited points), the hydrosphere, the pedosphere and potentials of land for use and development. Risk assessment was incorporated into suitability analysis as its third component; we excluded the most suitable areas where the risk was high (risk index 3 or 4 ) from the baseline suitability model for siting wind farms. For the baseline version of suitability (which does not take risk into account) and for the second one (which takes risk into account) we calculated the total area of places where wind farms (with an installed capacity of at least $10 \mathrm{MW}$ ) could be built. In the calculations we used an E-70 wind turbine with an installed capacity of $2.3 \mathrm{MW}$ produced by the German manufacturer Enercon (like the existing wind turbine in Dolenja Vas near Senožeče). We searched for locations where at least five such wind turbines could be built. Existing wind farms occupy on average between 12 and 57 ha/MW (Denholm et al., 2009). Data about the distance between turbines that can be found in the literature range from three to fifteen rotor diameters (Department of the Environment, 2007; Christie \& Bradley, 2012; Meyers \& Meneveau, 2011). We assumed that the distance between sample turbines in a row would be $215 \mathrm{~m}$ (three rotor diameters) and $355 \mathrm{~m}$ between rows (five rotor diameters), which means that we searched for locations measuring at least $200 \mathrm{~m} \times 1,000 \mathrm{~m}$ (for siting five wind turbines in a row) or $500 \mathrm{~m} \times 600 \mathrm{~m}$ (for siting five wind turbines in a cluster) among areas with the highest suitability on the spatial suitability map for siting wind farms. However, in Slovenian practice wind turbines in plans for siting wind farms are usually spaced wider apart. In the Senožeče Hills, for example, more than three or four turbines per $\mathrm{km}^{2}$ were planned at first, but due to the diverse terrain with other limitations wind turbines could not be spaced so densely. The last version of the plan for the Senožeče Hills specifies several different densities per $\mathrm{km}^{2}$, at some locations only one wind turbine and at some even no wind turbines. We calculated the investment and maintenance costs and the amount of energy produced for both versions of spatial suitability (with and without integration of risks) and, for suitability that does not take risks into account, also additional costs due to physical damage as a consequence of a severe ice storm. A third option for siting wind farms was analysed as well; a system for detecting and preventing ice accretion would be integrated into wind turbines in areas with higher risks whereas regular wind turbines would be built in other locations.

\subsection{Cost-benefit analysis}

Accretion of ice on wind turbines can lead to complete stoppage of turbines, resulting in significant energy loss, decreased power production due to disruption of aerodynamics and shortening the lifetime of the components, and uncontrolled ice throw from rotating blades poses a serious safety issue to people and facilities in the vicinity (Dalili et al., 2007; Grünevald et al., 2012). In November 2013, ice storms caused significant damage to wind turbines and the transmission system in Texas, which led to shutting down two wind farms with a combined capacity of $78 \mathrm{MW}$. Estimates to fix the damage exceeded the economic value of the projects at both facilities (Micek, 2014). A system for detecting ice accretion on rotor blades and preventing ice accumulation is available for modern wind farms (Deutsche WindGuard, 2011). To support the decision-making process about wind farm siting, we 


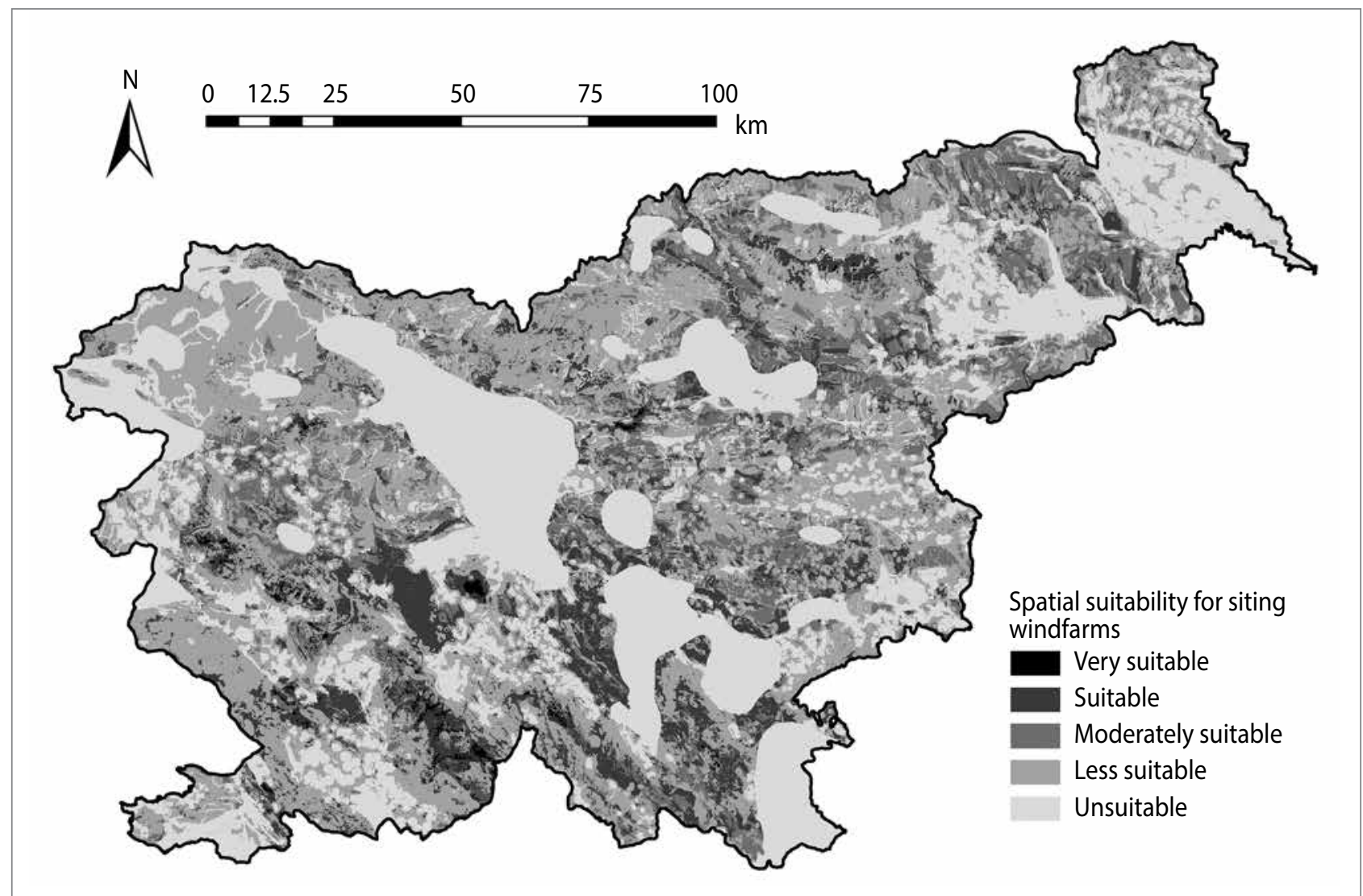

Figure 4: Spatial suitability for siting wind farms without consideration of risks due to ice storms (illustration: Maruša Matko).

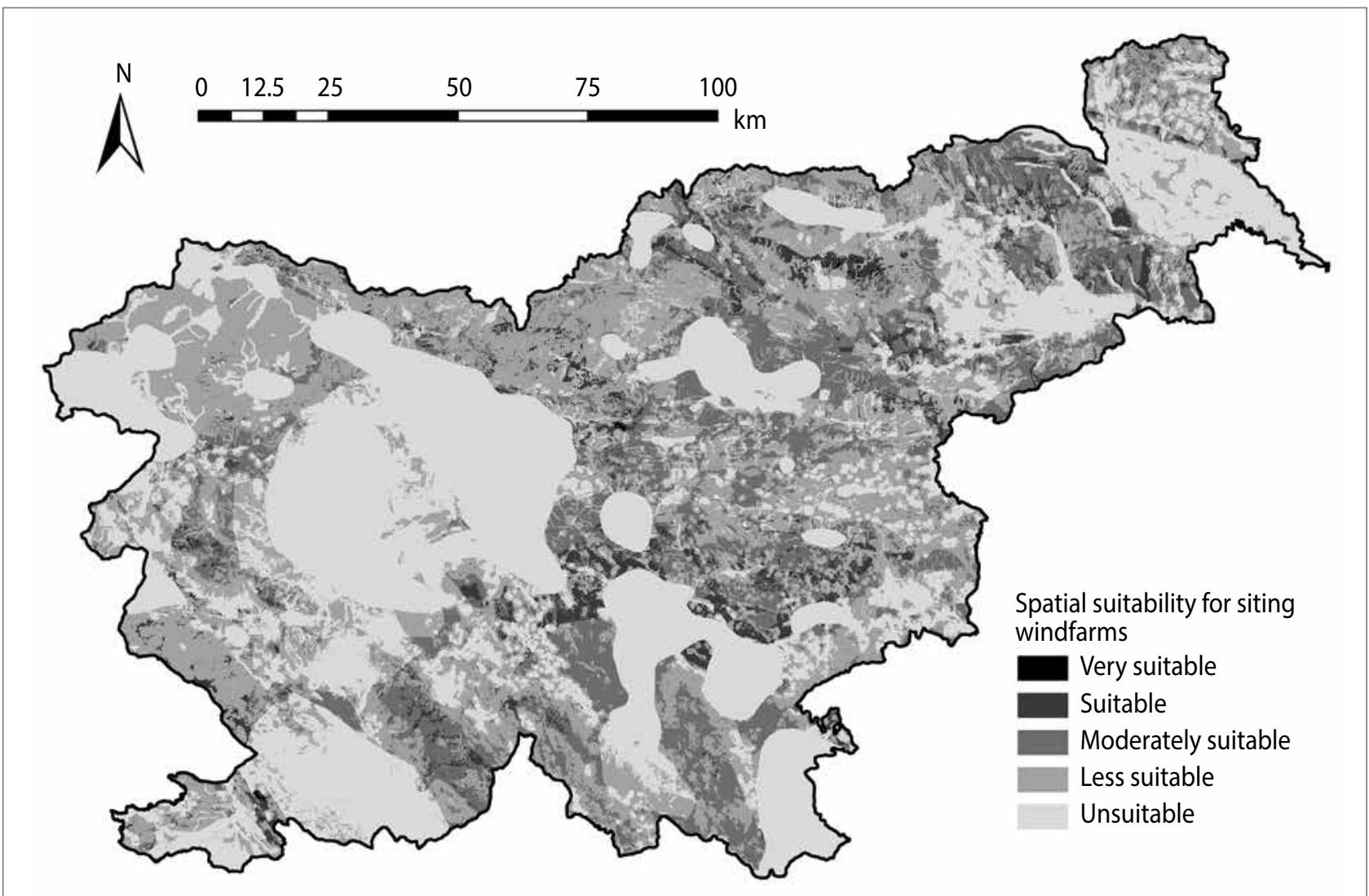

Figure 5: Spatial suitability for siting wind farms with consideration of risks due to ice storms (illustration: Maruša Matko). 
calculated how possible damage can affect the amount of energy produced and financially expressed damage due to possible repairs for both spatial suitability alternatives for siting wind farms in Slovenia. We analysed an additional alternative with a system for detecting and preventing ice accretion built into turbines located in the areas with highest risks. We considered a period of 25 to 50 years (rounded figures) because severe damage can occur during this period (risk index 3 , when damage to the transmission and distribution system amounts to between EUR 1 million and 10 million, frequency 0.037 /year and risk index 4, when damage is higher than EUR 10 million, frequency $0.0185 /$ year). The costs of construction, operation and maintenance were taken into account for all three alternatives for siting wind farms: the first one, which considers risk due to ice storms, the second one with a technical improvement (a system for detecting and preventing ice accretion) for wind turbines in the areas with the highest risk and the third one, which does not consider risk. Calculation of investment costs is based on data about investment in the existing wind turbine in Dolenja Vas near Senožeče (Ministry of Infrastructure of the Republic of Slovenia, 2013) and calculations by the National Renewable Energy Laboratory of the US Department of Energy (Moné et al., 2015). Investment costs amount to approximately EUR 3 million per wind turbine. A system for detecting ice and preventing its accumulation on turbines increases investment costs by 2 to $6 \%$ but it does not significantly affect the maintenance and operation costs (Eriksson, 2013). We used an average value of $4 \%$ in our calculations. The energy used for heating the rotor blades was not taken into account (pulsing, short-term impact). The availability of such wind turbines is slightly higher than those of turbines without an ice detection and accretion prevention system because of the energy used for heating and thawing glaze ice. The range of operation and maintenance costs is relatively high in the available literature. Ryan Wiser and Mark Bolinger (2014), for example, analysed empirical data about wind farms in the US and found that the maintenance and operation costs of wind farms built after 2010 amount to USD $23 / \mathrm{kW}$ annually. The data they considered did not always clearly state what is included in these costs, but in most of these cases maintenance and operation costs consist of wages, materials and rent. Christopher Moné et al. (2015), on the other hand, state that the figure from the aforementioned study considers only variable costs and does not include insurance, taxes, rents and amortisation. They calculated maintenance and operation costs considering these factors and the result was USD $50 / \mathrm{kW}$ annually. The costs of unplanned maintenance included random failures, but it is not clear from the study whether their cause can be EWE. In another study by the International Energy Agency (IEA, 2015), analyses of operation and maintenance costs in Denmark, Germany, Ireland, Norway, the European Union and the US were carried out. In 2012, annual costs of maintenance and operation were EUR 55.9/kw in Germany, EUR $55 / \mathrm{kW}$ in Ireland and USD $50 / \mathrm{kW}$ in the US. Data for some of the countries analysed were not provided due to high uncertainty. We used a value of EUR $56 / \mathrm{kW}$ in our calculations. Nick Middeldorf and Andreas Düing (2012) assumed that the land for building wind turbines would be purchased and that these costs are part of the investment. They included the maintenance contract with the turbine manufacturer, insurance, and energy and management costs in the maintenance and operation costs. According to their findings, annual costs of operation and maintenance for the Enercon E-70 wind turbine are EUR 13,000 in the first two years of operation and EUR 24,000 later on. We used all four sources of data in our calculations and compared one to another. These data are sufficient for the level of detail of our research, but for more detailed analyses consensus should be achieved on which maintenance and operation costs should be considered in Slovenia based on existing wind power plants and planned projects. The price of electric energy was calculated based on data on the market price of electric energy between 2009 and 2015 published by the Energy Agency of the Republic of Slovenia (Borzen, 2015), which is approximately EUR 50/MWh. There exists a feed-in tariff for large wind farms (EUR 52.64/ MWh in 2015), but due to uncertainties connected to future subsidies only the market price was considered in calculating the net present value (NPV). Consideration of subsidies in calculating the NPV would significantly affect the end result because the price of electric energy that includes subsidies is up to twice as high as the market price. In the period of observation, a discount rate of $2 \%$ was taken into account, which is the goal of the European Central Bank for the euro area. In the case of an ice storm, 190 wind turbines located in highrisk areas would be repaired. A turbine represents $68 \%$ of the entire investment (Moné et al., 2015), which amounts to a total of EUR 388 million.

\section{Results}

\subsection{Risk to electric energy infrastructure due to ice storms}

The result of the analysis of ice storms in terms of their intensity level and frequency of occurrence is the risk map presented in Figure 2. In the areas in white (Prekmurje and the coast), no damage was caused by ice storms in the period observed. On the other hand, greater damage (more than EUR 10 million) occurs most often (more than 0.2 times per year) in the darkest areas (the Brkini Hills, the hilly area near Idrija and Cerkno, and the surroundings of Logatec). Most of Slovenia has a risk index of 1 (light grey): damage to electric energy infrastructure is relatively low and occurs up to 0.2 times per year. The map of risk to electric energy infrastructure due to 
ice storms was overlaid by the map of glaze ice zones according to standard SIST EN 50341-3-21 for building high-voltage overhead lines (Slovenian Institute for Standardisation, 2009) as shown in Figure 2. The standard divides Slovenia into three zones based on the burden that should be considered in designing power lines. In Zone 1, the burden due to glaze ice is relatively small and did not cause any physical damage to power lines in the past. In Zone 2, a high burden due to glaze ice is expected, which damaged power lines in the past. In Zone 3 , a very high burden is expected based on meteorological conditions, geographic location and long-term experience. Such burdens caused significant damage to power lines in the past. Based on the findings from our risk assessment, it would be recommendable to update the standard: to extend Zone 3 to areas where the risk due to ice storm is the highest. Based on the data obtained, analyses and calculations carried out and the synthesis of results, we compared two proposed national spatial plan alternatives for upgrading the $400 \mathrm{kV}$ BeričevoDivača power line (Figure 3) in order to present the use of the described risk assessment in spatial planning for selecting the most suitable corridor. Considering the results presented in Figure 2, the southern corridor is more suitable for siting the new high-voltage Beričevo-Divača power line.

\subsection{Spatial suitability for siting wind farms}

The map of spatial suitability for siting wind farms that takes risk due to ice storms into account is presented in Figure 4. Slovenia has approximately $68 \mathrm{~km}^{2}$ suitable for building wind farms. Among these are areas suitable for siting at least five E-70 wind turbines manufactured by Enercon (e.g., the wind turbine in Dolenja Vas). The total area of these territories (without consideration of risk) is about $31 \mathrm{~km}^{2}$. Four hundred five sample turbines could be built there. Their total installed capacity would be $930 \mathrm{MW}$ and their total annual electric energy production (assuming that they would operate for 1,800 hours per year) would amount to $1.68 \mathrm{TWh}$. If highrisk areas are excluded, there are altogether $17 \mathrm{~km}^{2}$ suitable for building at least five wind turbines. These areas are presented in Figure 5. Two hundred fifteen wind turbines could be built there with a total installed capacity of $495 \mathrm{MW}$. Their total annual production of electric energy would be $890 \mathrm{GWh}$.

\subsection{Results of cost-benefit analysis}

Table 1 presents data about the NPV of costs and benefits for all three alternatives of siting wind farms without consideration of the occurrence of ice storms and with this consideration (in the latter case, the wind farms would be located outside high-risk areas and technical improvements for de-icing are included in the analysis). In the first alternative, in which wind farms would be located in all the most suitable areas including those with the highest risk (the darkest areas in Figure 2), costs are higher than benefits according to all data sources considered. The alternative that considers risk by including technical improvements (a rotor blade heating system) has a positive net present value (EUR 247 million) if low maintenance and operation costs are taken into account (Middeldorf \& Düing, 2012), the NPV is EUR 42 million if costs according to Wiser and Bolinger (2014) are considered, and the NPV is negative if costs calculated by Moné et al. (2015) and IEA (2015) are taken into account (negative EUR 403 million and negative EUR 605 million, respectively). The alternative that considers risk by not locating wind farms in areas subjected to high risk of ice storms has a positive NPV according to some data sources (EUR 143 million, Middeldorf \& Düing, 2012, or EUR 34 million, Wiser \& Bolinger, 2014) and negative NPV according to others (negative EUR 202 million, Moné et al., 2015, or negative EUR 311 million, IEA, 2015). The practical impact and result of these findings would be presented in several versions of Figure 2, depending on the point of views of investors and operators of wind farms; the primary version of Figure 2 would be adjusted based on the results of risk assessment and cost benefit analysis (NPV) in accordance with the number, type, equipment and location of new units. The expected result would be new maps that would include the difference between costs and benefits by presenting lower total costs as a lower category of damage and consequently lower risk index. These maps would form the basis for investors' final decision about investment as well as the basis for approving detailed spatial plans. To achieve this, the spatial planning procedure at the level of detailed spatial plans should allow for iterations of assessment of risk due to EWE.

\section{Discussion}

The method for integrating risk assessment into spatial planning of electric power infrastructure that was presented and tested in this study is transparent and operable and can provide support in the decision-making process. There are several ways of applying the risk assessment results to optimise electric power infrastructure. Optimisation of electric energy infrastructure that considers risk can be technical or spatial. In technical optimisation, the risk assessment results can be used to revise building codes (Figure 2: map of risk to electric energy infrastructure due to ice storms), making future facilities physically more resilient. One measure of technical optimisation is building wind turbines with an integrated ice detection and prevention system. The risk assessment results can also serve to support investment planning of maintenance of the existing infrastructure. In spatial optimisation, the approach can be used to compare various alternatives of the plan that has 
Table 1: Comparison of costs and benefits of building wind farms in a twenty-five-year period without taking into account risks due to ice storms (option 1) and with consideration of the risk assessment results (options 2 and 3).

\begin{tabular}{|c|c|c|c|c|c|}
\hline Option & NPV (costs) & & NPV (benefits) & $\begin{array}{l}\text { NPV (difference } \\
\text { between benefits } \\
\text { and costs) }\end{array}$ & $\begin{array}{l}\text { NSV (difference between } \\
\text { benefits and costs in } \\
\text { case of ice storm) }\end{array}$ \\
\hline \multirow{8}{*}{$\begin{array}{l}1 \text { (wind farms also } \\
\text { in areas where ice } \\
\text { storms can occur) }\end{array}$} & Investment: & -EUR 1.215 billion & $\begin{array}{l}\text { Electric energy sold: } \\
\text { +EUR } 1.67 \text { billion }\end{array}$ & $\begin{array}{l}\text { From -EUR } 582 \text { to } \\
\text { +EUR } 270 \text { million }\end{array}$ & $\begin{array}{l}\text { From -EUR } 118 \text { million } \\
\text { to -EUR } 970 \text { million }\end{array}$ \\
\hline & \multirow{4}{*}{$\begin{array}{l}\text { Costs of main- } \\
\text { tenance + ope- } \\
\text { ration: }\end{array}$} & $\begin{array}{l}\text {-EUR } 185 \text { million (Middel- } \\
\text { dorf \& Düing, 2012) }\end{array}$ & & & \\
\hline & & $\begin{array}{l}\text {-EUR } 390 \text { million (Wiser \& } \\
\text { Bolinger, 2014) }\end{array}$ & & & \\
\hline & & $\begin{array}{l}\text {-EUR } 835 \text { million (Moné et al., } \\
\text { 2015) }\end{array}$ & & & \\
\hline & & -EUR 1.037 billion (IEA, 2015) & & & \\
\hline & $\begin{array}{l}\text { Costs due to ice } \\
\text { storm: }\end{array}$ & -EUR 388 million & & & \\
\hline & Total costs: & $\begin{array}{l}\text { From EUR } 1.4 \text { billion to } \\
\text { EUR } 2.252 \text { billion }\end{array}$ & & & \\
\hline & $\begin{array}{l}\text { Total cost in } \\
\text { case of ice } \\
\text { storm }\end{array}$ & $\begin{array}{l}\text { from EUR } 1.788 \text { billion to } \\
\text { EUR } 2.640 \text { billion }\end{array}$ & & & \\
\hline \multirow{7}{*}{$\begin{array}{l}2 \text { (wind farms also } \\
\text { in areas where ice } \\
\text { storms can occur, } \\
\text { but wind turbines } \\
\text { in these areas } \\
\text { have a system for } \\
\text { icing detection } \\
\text { and prevention) }\end{array}$} & Investment: & -EUR 1.238 billion & $\begin{array}{l}\text { Electric energy sold: } \\
\text { +EUR } 1.67 \text { billion }\end{array}$ & $\begin{array}{l}\text { From -EUR } 605 \\
\text { million to } \\
\text { +EUR } 247 \text { million }\end{array}$ & $\begin{array}{l}\text { From -EUR } 605 \text { million } \\
\text { to +EUR } 247 \text { million }\end{array}$ \\
\hline & \multirow{4}{*}{$\begin{array}{l}\text { Costs of main- } \\
\text { tenance + ope- } \\
\text { ration: }\end{array}$} & $\begin{array}{l}\text {-EUR } 185 \text { million (Middel- } \\
\text { dorf \& Düing, 2012) }\end{array}$ & & & \\
\hline & & $\begin{array}{l}\text {-EUR } 390 \text { million (Wiser \& } \\
\text { Bolinger, 2014) }\end{array}$ & & & \\
\hline & & $\begin{array}{l}\text {-EUR } 835 \text { million (Moné et al., } \\
\text { 2015) }\end{array}$ & & & \\
\hline & & -EUR 1.037 billion (IEA, 2015) & & & \\
\hline & $\begin{array}{l}\text { Costs due to ice } \\
\text { storm: }\end{array}$ & EUR 0 & & & \\
\hline & Total costs: & $\begin{array}{l}\text { From EUR } 1.423 \text { billion to } \\
\text { EUR } 2.275 \text { billion }\end{array}$ & & & \\
\hline \multirow{7}{*}{$\begin{array}{l}3 \text { (wind farms } \\
\text { only in areas } \\
\text { where ice storms } \\
\text { do not occur) }\end{array}$} & Investment: & -EUR 645 million & $\begin{array}{l}\text { Electric energy sold: } \\
\text { +EUR } 886 \text { million }\end{array}$ & $\begin{array}{l}\text { From -EUR } 311 \\
\text { million to } \\
\text { +EUR } 143 \text { million }\end{array}$ & $\begin{array}{l}\text { From -EUR } 311 \text { million } \\
\text { to +EUR } 143 \text { million }\end{array}$ \\
\hline & \multirow{4}{*}{$\begin{array}{l}\text { Costs of main- } \\
\text { tenance + ope- } \\
\text { ration: }\end{array}$} & $\begin{array}{l}\text {-EUR } 98 \text { million (Middel- } \\
\text { dorf \& Düing, 2012) }\end{array}$ & & & \\
\hline & & $\begin{array}{l}\text {-EUR } 207 \text { million (Wiser \& } \\
\text { Bolinger, 2014) }\end{array}$ & & & \\
\hline & & $\begin{array}{l}\text {-EUR } 443 \text { million (Moné et al., } \\
\text { 2015) }\end{array}$ & & & \\
\hline & & -EUR 552 million (IEA, 2015) & & & \\
\hline & $\begin{array}{l}\text { Costs due to ice } \\
\text { storm: }\end{array}$ & EUR 0 & & & \\
\hline & Total costs: & $\begin{array}{l}\text { From EUR } 743 \text { million to } \\
\text { EUR } 1.197 \text { billion }\end{array}$ & & & \\
\hline
\end{tabular}

Data source for calculation: Middeldorf \& Düing (2012); Wiser \& Bolinger (2014); Moné et al. (2015); IEA (2015). 
already been proposed (as shown in the case study for proposed transmission lines, Figure 3) or it can be integrated into development of the plan itself by searching for locations where damage to the planned facilities will be lower or will not occur. Operationally, risk assessment is included in spatial suitability analysis as its third component, but conceptually it is a part of spatial (un)attractiveness. The method for integrating risk assessment into spatial planning of electric power infrastructure has been developed in cooperation with Slovenian electricity production, transmission and distribution companies. They assessed the approach we presented to them as promising and they are now running further tests to see how it can be applied to meet their needs. Testing the applicability in a wider context should include spatial planners and policy makers. The results presented can by all means stimulate public discussion on future energy demands and how to meet them, the energy mix and the consideration of various risks when choosing appropriate locations for future energy infrastructure.

The risk assessment result (a map of risk to Slovenian electric power infrastructure due to ice storms) showed which areas should be avoided in siting new electric energy infrastructure in order to prevent greater damage and on which existing infrastructure to implement measures to prevent or minimise damage. Recently, new risk maps have been prepared for France (Dalle \& Admirat, 2011), Italy (Bonelli et al., 2011), Switzerland (Grünevald et al., 2012), Canada (Lamraoui et al., 2013) and the UK (Nygaard et al., 2014). These maps are based on meteorological models and/or data obtained from meteorological stations and show areas where specific ice load or specific duration of icing is expected. Bjørn Nygaard et al. (2014) propose using risk maps in developing new building codes, and Bernard Dalle and Pierre Admirat (2011) and Paolo Bonelli et al. (2011) propose using them in designing power lines that are already proposed to be built at specific locations and in making decisions about technical measures for preventing ice accretion or its removal, but none of these authors mention searching for locations for future infrastructure based on the results of their risk assessments. Dalle and Admirat (2011) propose using a risk map in organising emergency repairs. Fayçal Lamraoui et al. (2013) state that a risk map can serve as a decision support tool in making decisions about implementing specific projects but they do not elaborate this idea further. Thomas Günevald et al. (2012) propose using a map of risk due to ice storms in planning wind farms in combination with maps of wind potential, but they do not develop the idea in detail. The studies presented mostly address technological optimisation and not searching for locations for new electric power infrastructure based on risk assessments, and this is why it is impossible to compare our results with others and hence we focus on the strengths and weaknesses of our approach that we encountered during its testing.
One of the issues raised during the application of the method presented is the availability of data. Monitoring EWE and the damage they cause is not standardised. The datasets from electric power transmission and distribution operators are very heterogeneous (they can record the number of customers without electricity, duration of interruption of power supply, amount of energy not supplied, and physical or financial loss). Proper assumptions and adaptations are therefore required before risk analyses can be undertaken. In the case presented, suitable data were available only for direct (physical) damage, and therefore the results show risk categories for the transmission and distribution companies. If data about energy not supplied were available, the financial loss suffered by customers and indirect loss suffered by the economy could be calculated. It would make sense to standardise the recording of data about damage. The length of time series of data about damage depends on a company; data recorded before the existence of electronic archives are especially difficult to obtain. This can contribute to lesser accuracy of risk assessment, especially if the operator with such data is responsible for the infrastructure in locations where EWE often occur and cause significant damage. Damage caused by EWE to the environment can cause additional damage to infrastructure. This was taken into account in risk assessment by considering damage in forests. Available data on costs of wind turbines are very heterogeneous as well and the choice of the data source can have a decisive impact on the net present value of the proposed project, as shown in Table 1. The sources of data considered in our calculations differ in their definition of operation and maintenance costs (e.g., some count land rentals among operation and maintenance costs whereas others assume that the land would be purchased and that the land price would be part of the investment costs). There are also differences between the data depending on the countries considered in these studies. This is why a discussion on the data used in the cost-benefit analysis should be held before making decisions about siting wind farms in Slovenia. There are additional uncertainties connected to future incentives for using renewable energy sources and therefore only the market price of electricity in Slovenia was taken into account in calculations of benefits due to electric power sold, whereas the subsidised price (which can be two times higher than the market price) was not considered. In the case of an ice storm, the costs of wind farms are higher than the benefits. This finding is consistent with the actual case from practice when stopping the operation of wind farms was chosen over their repair (Micek, 2014).

\section{Conclusion}

The aim of this article was to design, test and present a method that would integrate risk assessment into spatial planning tools. 
The approach presented proved to be useful in spatial planning as well as in making decisions about enhancing mechanical resilience, which includes decisions about maintaining and reconstructing electric power infrastructure. Our hypothesis that integrating risk assessment into spatial planning can reduce the damage to energy infrastructure caused by EWE was confirmed. The approach developed was presented in a case study of ice storms in Slovenia and siting wind farms, but it can be applied to other types of extreme weather events and various combinations of these events as well as to various geographical scales and regions. The application of the method is not limited to energy infrastructure; it can be used to assess risks to other critical infrastructure as well as other elements of the environment, both natural (e.g., forest, soil, watercourses, etc.) and manmade (e.g., settlements, cultural heritage, etc.). The level of detail of the risk assessment can be adjusted both in the geographic scale (size of the area of examination) and in the level of detail of analyses. Future research should include all of the aspects mentioned and assess risks due to other types of EWE causing damage to electric power infrastructure (strong wind, heavy snow, hail and heavy rain that causes flooding and erosion) due to combinations of these events and for other electric power infrastructure (e.g., photovoltaic panels, hydroelectric power plants and nuclear power plants). The next step of the research should include an analysis of application of the approach to designing maintenance and reconstruction measures for existing infrastructure and to cost-effectiveness analyses of these measures; for example, a comparison of the costs of protective measures against potential damage due to extreme events.

During the research, the question was raised how to address events that have not been experienced so far. It would be recommendable to use climate models that simulate changes in the frequency of occurrence and intensity of EWE, but these models usually have coarse resolution and are related to uncertainties in future emission scenarios, design of climate models and their downscaling from the global to regional and local levels, as well as to nonlinear relationships between mean values and extreme weather events (Mearns et al., 1984; Jones, 2001; Mitchell et al., 2006; Fowler et al., 2007; Van Aalst, 2006; Chen et al., 2011; Ceglar \& Kajfež-Bogataj, 2012; IPCC, 2012; Sunyer et al., 2012, and Willems et al., 2012). The certainty of projections of the occurrence of EWE depends greatly on the types of extremes and the regions considered (Planton et al. 2008; IPCC 2012). Modelling impacts of EWE on a specific system (e.g., agriculture, forests and the energy sector) constitute an additional source of uncertainty (Fowler et al. 2007). For better prediction of the impact of climate change on electric power infrastructure, various combinations of climate change scenarios and scenarios of future energy and social development, as well as details of planned energy infra- structure, may be used. Some types of electric energy infrastructure are relatively new (e.g., photovoltaic panels) and little information is available about their susceptibility to damage due to various types of EWE. There are also some territories that have had no infrastructure in the past, but it might be located there in the future. To reduce the degree of uncertainty, sufficient reliable data have to be obtained for various locations and infrastructure as well as for other elements of the environment. A standardised system for recording data about the impact of EWE on electric power and other infrastructure should therefore be proposed to operators of these facilities. Appropriate caution is necessary when various types of facilities (i.e., power units) are analysed. The results (i.e., risk index categories) may appear to be equal for all units, but in absolute terms (e.g., energy not delivered) this is not the case: there may be differences in orders of magnitude (e.g., comparison between energy production at a hydroelectric power plant and the nuclear power plant in Slovenia). Therefore, when interpreting risk indices and related costs, the context and energy infrastructure involved should be specified. It has yet to be experienced in practice how the method presented can be applied in formal spatial planning procedures. Consensus with spatial planners and other stakeholders in procedures should be achieved about this. Agreement with experts is expected to be reached quickly, whereas negotiation with administrative authorities may take longer. We believe that integrating the approach presented into existing spatial planning procedures requires only minor adaptations according to specific land-use planning contexts, levels of detail and needs or expectations.

\section{Acknowledgements}

This research was carried out with the support of the European Social Fund, the Ministry of Education, Science and Sport of the Republic of Slovenia and the International Atomic Energy Agency. We thank representatives from Slovenian electricity production, transmission and distribution companies (Dravske Elektrarne Maribor, ELES, Elektro Celje, Elektro Gorenjska, Elektro Ljubljana, Elektro Maribor, Elektro Primorska, Hidroelektrarne na Spodnji Savi, Nuklearna Elektrarna Krško, Savske Elektrarne Ljubljana, SODO and Soške Elektrarne Nova Gorica) for cooperation in workshops and for the data provided.

\section{Maruša Matko}

Jožef Stefan Institute, Ljubljana, Slovenia

E-mail: marusa.matko@ijs.si

\section{Mojca Golobič}

University of Ljubljana, Biotechnical Faculty, Department of Landscape Architecture, Ljubljana, Slovenia

E-mail:mojca.golobic@bf.uni-lj.si

Branko Kontić

Jožef Stefan Institute, Ljubljana, Slovenia

E-mail:branko.kontic@ijs.si 


\section{References}

Administration of the Republic of Slovenia for Civil Protection and Disaster Relief (2014) Šifrant F - Povprečne cene po skupinah del v elektroenergetskem omrežju. Available at: http://www.sos112.si (accessed 10 Jun. 2015).

Alder, S., Prasuhn, V., Liniger, H., Herweg, K., Hurni, H., Candinas, A., et al. (2015) A high-resolution map of direct and indirect connectivity of erosion risk areas to surface waters in Switzerland - A risk assessment tool for planning and policy-making. Land Use Policy, 48(1), pp. 236-249. DOI: 10.1016/j.landusepol.2015.06.001

Andersson-Sköld, Y., Thorsson, S., Rayner, D., Lindberg, F., Janhäll, S., Jonsson, A., et al. (2015) An integrated method for assessing climaterelated risks and adaptation alternatives in urban areas. Climate Risk Management, 7, pp. 31-50. DOI: 10.1016/j.crm.2015.01.003

Auld, H., Maclver, D. \& Klaassen, J. (2006) Adaptation options for infrastructure under changing climate conditions. In: Proceedings of engineering institute of Canada climate change technology conference, pp. 1-11. Piscataway, NJ, Institute of Electrical and Electronics Engineers. DOI: $10.1109 /$ eicccc. 2006.277248

Bahun, P. (2014) Slovenija v ledenem objemu. Črni petek za slovensko elektroenergetsko omrežje. Naš stik: glasilo delavcev Elektrogospodarstva Slovenije, 32(1), pp. 2-5.

Bahun, P., Janjić, B., Habjan, V. \& Jakomin, M. (2014) Žledolom povzročil za več deset milijonov evrov škode. Naš stik: glasilo delavcev Elektrogospodarstva Slovenije, 32(2), pp. 2-16.

Belak, L. \& Maruša, R. (2014) Žled 2014 in ukrepi za odpravljanje ledu na vodnikih prenosnih vodov. Paper presented at the 2 nd Slovenian Conference on Maintenance of Electric Power Transmission and Distribution Infrastructure, 12 Nov., Nova Gorica, Slovenia. Typescript.

Belak, L., Maruša, R., Ferlič, R., Ribič, J. \& Pihler, J. (2014) Analiza žledoloma 2014 v prenosnem omrežju Elektra Slovenija. Paper presented at the 23rd International Power Engineering Expert Meeting, 13-15 May, Maribor, Slovenia. Typescript.

Berry, M. \& BenDor, T. K. (2015) Integrating sea level rise into development suitability analysis. Computers, Environment and Urban Systems, 51, pp. 13-24. DOI: 10.1016/j.compenvurbsys.2014.12.004

Biesbroek, G. R., Swart, R. J. \& Van der Knaap, W. G. M. (2009) The mitigation-adaptation dichotomy and the role of spatial planning. Habitat International, 33(3), pp. 230-237. DOI: 10.1016/j.habitatint.2008.10.001

Bogataj, F. (1997) Katastrofalne posledice žledu. Logaške novice, 28(1), p. 2.

Bonelli, P., Lacavalla, M., Marcacci, P., Mariani, G. \& Stella, G. (2011) Wet snow hazard for power lines: A forecast and alert system applied in Italy. Natural Hazards and Earth System Sciences, 11, pp. 2419-2431. DOI: 10.5194/nhess-11-2419-2011

Borzen (2015) Določanje višine podpor električni energiji proizvedeni iz OVE in SPTE in višine podpor v letu 2015. Available at: https://www. borzen.si (accessed 4 Aug. 2015).

Briggs, J., Forer, P., Järup, L. \& Stern, R. (eds.) (2002) GIS for emergency preparedness and health risk reduction. Dordrecht, Kluwer Academic Publishers. DOI: 10.1007/978-94-010-0616-3

Camarasa-Belmonte, A. M. \& Soriano-García, J. (2012) Flood risk assessment and mapping in peri-urban Mediterranean environments using hydrogeomorphology. Application to ephemeral streams in the Valencia region (eastern Spain). Landscape and Urban Planning, 104(2), pp. 189-200. DOI: 10.1016/j.landurbplan.2011.10.009
Canters, F., Vanderhaegen, S., Khan, A. Z., Engelen, G. \& Uljee, I. (2014) Land-use simulation as a supporting tool for flood risk assessment and coastal safety planning: The case of the Belgian coast. Ocean \& Coastal Management, 101, pp. 102-113. DOI: 10.1016/j.ocecoaman.2014.07.018

Cardona, O. D. (2003) The need for rethinking the concepts of vulnerability and risk from a holistic perspective: $A$ necessary review and criticism for effective risk management. In: Bankoff, G., Frerks, G. \& Hilhorst D (eds.) Mapping vulnerability: Disasters, development and people. London, Earthscan Publishers.

Ceglar, A. \& Kajfež-Bogataj, L. (2012) Simulation of maize yield in current and changed climatic conditions: Addressing modelling uncertainties and the importance of bias correction in climate model simulations. European Journal of Agronomy, 37(1), pp. 83-95. DOI: 10.1016/j.eja.2011.11.005

Chen, J., Brissette, F. P. \& Leconte, R. (2011) Uncertainty of downscaling method in quantifying the impact of climate change on hydrology. Journal of Hydrology, 401(3-4), pp. 190-202.

DOI: 10.1016/j.jhydrol.2011.02.020

Christie, D. \& Bradley, M. (2012) Optimising land use for wind farms. Energy for Sustainable Development, 16(4), pp. 471-475. DOI: 10.1016/j.esd.2012.07.005

Cortekar, J. \& Groth, M. (2015) Adapting energy infrastructure to climate change - Is there a need for government interventions and legal obligations within the German "Energiewende"? Energy Procedia, 73, pp. 12-17. DOI: 10.1016/j.egypro.2015.07.552

Council Directive 96/82/EC of 9 December 1996 on the control of majoraccident hazards involving dangerous substances. Official Journal of the European Union, no. 10/1997. Brussels.

Dalili, N., Edrisy, A. \& Carriveau, R. (2007) A review of surface engineering issues critical to wind turbine performance. Renewable and Sustainable Energy Reviews, 13(2), pp. 428-438. DOI: 10.1016/j.rser.2007.11.009

Dalle, B. \& Admirat, P. (2011) Wet snow accretion on overhead lines with French report of experience. Cold Regions Science and Technology, 65(1), pp. 43-51. DOI: 10.1016/j.coldregions.2010.04.015

De Bruin, K., Goosen, H., van lerland, E. C. \& Groeneveld, R. A. (2013) Costs and benefits of adapting spatial planning to climate change: Lessons learned from a large-scale urban development project in the Netherlands. Regional Environmental Change, 13(2), pp. 1009-1020. DOI: 10.1007/s10113-013-0447-1

Denholm, P., Hand, M., Jackson, M. \& Ong, S. (2009) Land-use requirements of modern wind power plants in the United States. Available at: http://www.nrel.gov (accessed 23 Oct. 2015).

Department of the Environment (2007) Draft planning policy statement 18: Renewable energy. Consultation paper. Available at: http://www.planningni.gov.uk (accessed 28 Oct. 2015).

Deutsche WindGuard (2011) Summary of a technical validation of Enercon's rotor blade deicing system. Available at: http://www.svevind.se (accessed 20 Oct. 2015).

Dubois, C., Cloutier, G., Potvin, A., Adolphe, L. \& Joerin, F. (2015) Design support tools to sustain climate change adaptation at the local level: A review and reflection on their suitability. Frontiers of Architectural Research, 4(1), pp. 1-11. DOI: 10.1016/j.foar.2014.12.002

Elektro Slovenija (2015) Podatki o preteklih škodah na prenosnem omrežju zaradi žleda. Typescript (received in June 2015).

Eriksson, K. (2013) Icing status review. Available at: http://www.powervast.se (accessed 6 Nov. 2015).

European Commission (2007) Green paper of 29 June 2007 on adapting to climate change in Europe - options for EU action. Brussels. 
European Commission (2009) White paper: Adapting to climate change: Towards a European framework for action. Brussels.

European Commission (2011) Territorial agenda of the European Union. Gödöllő.

European Commission (2013) The EU strategy on adaptation to climate change. Brussels.

Feeley, T. J. III., Skone, T. J., Stiegel, G. J. Jr., McNemar, A., Nemeth, M. Schimmoller, B., et al. (2008) Water: A critical resource in the thermoelectric power industry. Energy, 33(1), pp. 1-11.

DOI: 10.1016/j.energy.2007.08.007

Flannery, W., Lynch, K. \& Cinneide, M. O. (2015) Consideration of coastal risk in the Irish spatial planning process. Land Use Policy, 43, pp. 161169. DOI: 10.1016/j.landusepol.2014.11.001

Foudi, S., Osés-Eraso, N. \& Tamayo, I. (2015) Integrated spatial flood risk assessment: The case of Zaragoza. Land Use Policy, 42, pp. 278-292. DOI: 10.1016/j.landusepol.2014.08.002

Fowler, H. J., Blenkinsop, S. \& Tebaldi, C. (2007) Linking climate change modelling to impacts studies: Recent advances in downscaling techniques for hydrological modelling. International Journal of Climatology, 27(12), pp. 1547-1578. DOI: 10.1002/joc.1556

Gall, M., Nguyen, K. H. \& Cutter, S. L. (2015) Integrated research on disaster risk: Is it really integrated? International Journal of Disaster Risk Reduction, 12, pp. 255-267. DOI: 10.1016/j.ijdrr.2015.01.010

Golobič, M., Praper Gulič, S., Gulič, A. \& Cof, A. (2012) Prilagajanje podnebnim spremembam z orodji prostorskega načrtovanja. Research project in the framework of CRP "Konkurenčnost Slovenije 2006-2013": final report. Ljubljana, Urban Planning Institute of the Republic of Slovenia.

Government Office of the Republic of Slovenia for Climate Change (2011) Predlog zakona o podnebnih spremembah (3. osnutek). Ljubljana.

Greiving, S. \& Fleischhauer, M. (2012) National climate change adaptation strategies of European states from a spatial planning and development perspective. European Planning Studies, 20(1), pp. 27-48.

DOI: 10.1080/09654313.2011.638493

Greiving, S., Fleischhauer, M. \& Wanczura, S. (2006) Management of natural hazards in Europe: The role of spatial planning in selected EU member states. Journal of Environmental Planning and Management, 49(5), pp. 739-757. DOI: 10.1080/09640560600850044

Grünevald, T., Dierer, S., Cattin, R., Steiner, P., Steinkogler, W., Fundel, F., et al. (2012) Mapping frequencies of icing on structures in Switzerland. Journal of Wind Engineering and Industrial Aerodynamics, 107-108, pp. 76-82. DOI: 10.1016/j.jweia.2012.03.022

Habjan, V. (2010) Žled podiral daljnovodne stebre: Poškodbe distribucijskega omrežja Elektra Primorska. Naš stik: glasilo delavcev Elektrogospodarstva Slovenije, 29(1), p. 30.

Habjan, V. \& Bahun, P. (2009) Ukrepi ob ujmah usmerjeni v čimprejšnjo sanacijo razmer. Naš stik: glasilo delavcev Elektrogospodarstva Slovenije, 28(2), pp. 2-9.

Hurlimann, A. C. \& March, A. P. (2012) The role of spatial planning in adapting to climate change. Wiley Interdisciplinary Reviews: Climate Change, 3(5), pp. 477-488. DOI: 10.1002/wcc.183

Intergovernmental Panel on Climate Change (2007) Summary for policymakers. In: Parry, M. L., Canziani, O. F., Palutikof, J. P., van der Linden, P. J. \& Hanson, C. E. (eds.) Climate change 2007: Impacts, adaptation and vulnerability. Contribution of working group II to the fourth assessment report of the intergovernmental panel on climate change, pp. 1-18. Cambridge, Cambridge University Press.

Intergovernmental Panel on Climate Change (2012) Summary for policymakers. In: Field, C. B., Baros, V., Stocker, T. F., Qin, D., Dokken, D. J.,
Ebi, K. L., et al. (eds.) Managing the risks of extreme events and disasters to advance climate change adaptation: A special report of working groups I and II of the intergovernmental panel on climate change, pp. 3-21. Cambridge, Cambridge University Press. DOI: 10.1017/CBO9781139177245

Intergovernmental Panel on Climate Change (2013) Summary for policymakers. In: Stocker, T. F., Qin, G., Plattner, G.-K., Tignor, M., Allen, S. K. Boschum, J., et al. (eds.) Climate change 2013: The physical science basis. Contribution of working group I to the fifth assessment report of the intergovernmental panel on climate change, pp. 1-36. Cambridge, Cambridge University Press.

International Atomic Energy Agency (2013) Techno-economic evaluation of options for adapting nuclear and other energy infrastructure to long-term climate change and extreme weather. Paper presented at the 1st research coordination meeting of the coordinated research project titled Techno-economic evaluation of options for adapting nuclear and other energy infrastructure to long-term climate change and extreme weather, 10-12 April, Vienna, Austria. Typescript.

International Commission for the Protection of the Alps (2010) Spatial planning in climate change: A CIPRA background report. Schaan.

International Energy Agency (2015) IEA Wind Task 26: Wind technology, cost, and performance trends in Denmark, Germany, Ireland, Norway, the European Union, and the United States: 2007-2012. Available at: https:// www.ieawind.org (accessed 6 Nov. 2015).

Jakomin, M. (2014) Zimska ujma opozorila na ranljivost in podhranjenost omrežja. Naš stik: glasilo delavcev Elektrogospodarstva Slovenije, 32(2), pp. 28-29.

Jakša, J. (1997) Posledice snegoloma in žledoloma v gozdovih leta 1996. Ujma, 11, pp. 49-62.

Jakše, J. (1997) Havarije v slovenski prenosni mreži. In: Pregl, M. (ed.) Jeklene konstrukcije imajo bodočnost, pp. 95-103. Ljubljana, Institute of Metal Constructions.

Jones, R. N. (2001) An environmental risk assessment/management framework for climate change impact assessments. Natural Hazards, 23(2), pp. 197-230. DOI: 10.1023/A:1011148019213

Jožef Stefan Institute (2011) Osnutek predloga Nacionalnega energetskega programa: Dolgoročne energetske bilance Republike Slovenije za obdobje 2010 do 2030 - izhodišča. Ljubljana.

Kajfež-Bogataj, L., Ceglar, A., Črepinšek, Z. \& Medved-Cvikl, B. (2012) Zakonodajne rešitve na področju prilagajanja na podnebne spremembe $v$ okviru predloga Zakona o podnebnih spremembah. Ljubljana, University of Ljubljana, Biotechnical faculty, Agrometeorological Centre.

Kastelec, D. (1997) Pojav žleda v Sloveniji. Ljubljana, Hydrological and Meteorological Service of the Republic of Slovenia.

Kern, J. \& Zadnik, B. (1987) Žledenje in elektrogospodarstvo. Ujma, 1 pp. 31-35.

Koblar, J., Marušič, J., Mejač, Ž. \& Jug, M. (1997) Environment vulnerability maps as an input for the national plan of Slovenia. In: Methods, tools and techniques of assessing the effects of development / 17th annual meeting, pp. 37-43. New Orleans, International Association for Impact Assessment.

Kontić, D. \& Kontić, B. (2008) Introduction of threat analysis into the land-use planning process. Journal of Hazardous Materials, 163(2-3), pp. 683-700.

Kopytko, N. \& Perkins, J. (2011) Climate change, nuclear power, and the adaptation-mitigation dilemma. Energy Policy, 39(1), pp. 318-333. DOI: 10.1016/j.enpol.2010.09.046

Kumar, P. \& Geneletti, D. (2015) How are climate change concerns addressed by spatial plans? An evaluation framework, and an application to Indian cities. Land Use Policy, 42, pp. 210-226.

DOI: 10.1016/j.landusepol.2014.07.016 
Lamraoui, F., Fortin, G., Benoit, R., Perron, J. \& Masson, C. (2013) Atmospheric icing severity: Quantification and mapping. Atmospheric Research, 128, pp. 57-75. DOI: 10.1016/j.atmosres.2013.03.005

Lancaster University (2007) Assessing and mapping multiple risks for spatial planning: Approaches, methodologies and tools in Europe. Lancaster, Lancaster University, Department of Geography.

Lapajne, S. (1997) Lomi daljnovodnih stebrov. Gradbeni vestnik, 46(1-3), pp. 7-8.

Linkaits, T. (2013) Vision and strategies around the Baltic Sea (VASAB): Spatial planning and climate change adaptation. Paper presented at the conference titled the 3rd policy forum climate change - adaptation in the Baltic Sea region, 30 May, Tallinn, Estonia. Typescript.

Marušič, J. (1993) Conservation planning within a framework of landscape planning in Slovenia. Landscape and Urban Planning, 23(3-4), pp. 233-239. DOI: 10.1016/0169-2046(93)90071-K

Marušič, J., Golobič, M., Mejač, ž. \& Jug, M. (2004) Environmental assessment of developmental vision through landscape vulnerability analyses. Landscape 21, 1, pp. 37-43.

Marušič, J, Kontić, B., Polič, S., Anko, B., Kos, D. \& Polič, M. (1993) Technical basis for determination of content and methodology for environmental vulnerability assessment. Ljubljana, Jožef Stefan Institute.

Matko, M., Golobič, M. \& Kontić, B. (2015) Ocena neposredne in povezane škode na energetski infrastrukturi zaradi izrednih vremenskih dogodkov: primer žleda. Ujma, 29, pp. 206-213.

McColl, L., Angelini, T. \& Betts, R. (2012) Climate change risk assessment for the energy sector. UK climate change risk assessment. London, Department for Environment, Food and Rural Affairs.

Mearns, L. O., Katz, R. W. \& Schneider, S. H. (1984) Extreme hightemperature events: Changes in their probabilities with changes in mean temperature. Journal of Climate and Applied Meteorology, 23(12), pp. 1601-1613. DOI: 10.1175/1520-0450(1984)023<1601:EHTECI>2.0. $\mathrm{CO} ; 2$

Meyers, J. \& Meneveau, C. (2011) Optimal turbine spacing in fully developed wind farm boundary layers. Wind Energy, 15(2), pp. 305-317. DOI: $10.1002 /$ we.469

Micek, K. (2014) NextEra Energy to shut two Texas wind farms in a first for ERCOT. Available at: http://www.platts.com (accessed 3 Aug. 2015).

Middeldorf, N. \& Düing, A. (2012) Wind power Ltd. Aachen, RWTH Aachen University.

Ministry of Infrastructure of the Republic of Slovenia (2015) Predlog usmeritev za pripravo Energetskega koncepta. Available at: http://www. energetika-portal.si (accessed 18 Aug. 2015).

Ministry of Infrastructure of the Republic of Slovenia (2015) Prva vetrna elektrarna v Sloveniji uradno odprta. Available at: http://www.energetikaportal.si (accessed 4 Aug. 2015).

Mitchell, J. F. B., Lowe, J., Wood, R. A. \& Vellinga, M. (2006) Extreme events due to human-induced climate change. Philosophical Transactions of the Royal Society, 364(1845), pp. 2117-2133.

Moné, C., Smith, A., Maples, B. \& Hand., M. (2015) 2013 Cost of wind energy review. Available at: http://www.nrel.gov (accessed 3 Aug. 2015).

Nadižar, M. \& Papler, D. (1997) Zaradi žleda brez elektrike okrog 15000 gospodinjstev. Gorenjski glas, 50(2), p. 11.

Nygaard, B. E. K., Seierstad, I. A. \& Veal, A. T. (2014) A new snow and ice load map for mechanical design of power lines in Great Britain. Cold Regions Science and Technology, 108, pp. 28-35. DOI: 10.1016/j. coldregions.2014.09.001

Panteli, M. \& Mancarella, P. (2015) Influence of extreme weather and climate change on the resilience of power systems: Impacts and possible mitigation strategies. Electric Power Systems Research, 127, pp. 259-270. DOI: 10.1016/j.epsr.2015.06.012

Papler, D. (1996) Več kot 5000 gospodinjstev brez elektrike: Žled povsod po Gorenjskem trgal kable, podiral drevje in drogove. Gorenjski glas, 49(103), p. 28.

Patt, A., Pfenniger, S. \& Lilliestam, J. (2013) Vulnerability of solar energy infrastructure and output to climate change. Climatic Change, 121(1), pp. 93-102. DOI: 10.1007/s10584-013-0887-0

Planton, S., Déqué, M., Chauvin, F. \& Terray, L. (2008) Expected impacts of climate change on extreme climate events. Comptes Rendus Geoscience, 340(9-10), pp. 564-574. DOI: 10.1016/j.crte.2008.07.009

Prawiranegara, M. (2014) Spatial multi-criteria analysis (SMCA) for basinwide flood risk assessment as a tool in improving spatial planning and urban resilience policy making: A case study of Marikina river basin, metro Manila - Philippines. Procedia - Social and Behavioral Sciences, 135, pp. 18-24. DOI: 10.1016/j.sbspro.2014.07.319

Pütz, M., Kruse, S., Casanova, E. \& Butterling, M. (2011) Climate change fitness of spatial planning. Research report. Bern, ETC Alpine Space Project CLISP.

Radinja, D. (1983) Žledne ujme v Sloveniji. In: Gams, I., Orožen Adamič, M., Rupert, M. \& Vivod, V. (eds.) Naravne nesreče v Sloveniji kot naša ogroženost, pp. 107-115. Ljubljana, Research Centre of the Slovenian Academy of Sciences and Arts, Anton Melik Geographical Institute.

Rannow, S., Loibl, W., Greiving, S., Gruehna, D. \& Meyer, B. C. (2010) Potential impacts of climate change in Germany - Identifying regional priorities for adaptation activities in spatial planning. Landscape and Urban Planning, 98(3-4), pp. 160-171.

DOI: 10.1016/j.landurbplan.2010.08.017

Rastandeh, A. (2015) Challenges and potentials in using alternative landscape futures during climate change: A literature review and survey study. Urbani izziv, 26(2), pp. 83-102.

DOI: 10.5379/urbani-izziv-en-2015-26-02-001

Rebula, E. (2001) Poškodbe zaradi žleda v Hrušici in Nanosu. Gozdarski vestnik, 59(3), pp. 147-154.

Rebula, E. (2002) Žled v notranjskih gozdovih in njegove posledice. Ujma, 16, pp. 156-166.

Resolucija o Nacionalnem energetskem programu. Uradni list Republike Slovenije, no. 57/2004. Ljubljana.

Rivera, C. \& Wamsler, C. (2014) Integrating climate change adaptation, disaster risk reduction and urban planning: A review of Nicaraguan policies and regulations. International Journal of Disaster Risk Reduction, 7, pp. 78-90. DOI: 10.1016/j.jijrr.2013.12.008

Rübbelke, D. \& Vögele, S. (2011) Impacts of climate change on European critical infrastructures: The case of the power sector. Environmental Science and Policy, 14, pp. 53-63. DOI: 10.1016/j.envsci.2010.10.007

Schaeffer, R., Szklo, A. S., Lucena, A. F. P., Borba, B. S. M. C., Nogueira, L. P. P., Fleming, F. P., et al. (2012) Energy sector vulnerability to climate change: A review. Energy, 38(1), pp. 1-2.

DOI: 10.1016/j.energy.2011.11.056

Serrao-Neumann, S., Crick, F., Harman, B., Schuch, G. \& Low Choy, D. (2015) Maximising synergies between disaster risk reduction and climate change adaptation: Potential enablers for improved planning outcomes. Environmental Science and Policy, 50, pp. 46-61. DOI: 10.1016/j.envsci.2015.01.017

Sieber, M. (2013) Impacts of, and adaptation options to, extreme weather events and climate change concerning thermal power plants. Climatic Change, 121(1), pp. 55-66. DOI: 10.1007/s10584-013-0915-0

Šifrer, M. (1977) Geografski učinki žleda v gozdovih okrog Idrije ter Postojne. Geografski zbornik, 16, pp. 195-228. 
Sinjur, I., Kolšek, M., Race, M. \& Vertačnik, G. (2010) Žled v Sloveniji januarja 2010. Gozdarski vestnik, 68(2), pp. 123-130.

Šipec, S. (1997) Pregled nesreč leta 1996. Ujma, 11, pp. 7-14.

Slovenia Forest Service (2014) Naravne ujme in požari večjih razsežnosti v Sloveniji. Available at: http://www.zgs.si (accessed 17 Feb. 2014).

Slovenian Institute for Standardization, The (2009) Slovenski standard SIST EN 50341-3-21, Nadzemni električni vodi za izmenične napetosti nad 45 kV. Del 3-21, Nacionalno normativna določila (NNA) za državo Slovenijo (na podlagi SIST EN 50341-1:2002). Ljubljana.

Špehar, U. (1998) Največ dela povzročil žled: kranjska območna enota zavoda za gozdove o lanskem delu. Gorenjski glas, 51(7), p. 10

Statistical Office of the Republic of Slovenia (2015) Odkup lesa. Available at: http://pxweb.stat.si (accessed 20 Jul. 2015).

Storch, H. \& Downes, N. (2013) Risk management and spatial planning - understanding rapid urbanization in climate change. In: Schrenk, M., Popovich, V. V., Zeile, P. \& Elisei, P. (eds.) REAL CORP 2013: Planning Times: You better keep planning or you get in deep water, for the cities they are a-changin'..., pp. 1327-1333. Schwechat-Rannersdorf, Competence Center of Urban and Regional Planning.

Sudmeier-Rieux, K., Fra.Paleo, U., Garschagen, M., Estrella, M., Renaud, F. G. \& Jaboyedoff, M. (2015) Opportunities, incentives and challenges to risk sensitive land use planning: Lessons from Nepal, Spain and Vietnam. International Journal of Disaster Risk Reduction, 14(3), pp. 205-224. DOI: 10.1016/j.ijdrr.2014.09.009

Sunyer, M. A., Madsen, H. \& Ang, P. H. (2012) A comparison of different regional climate models and statistical downscaling methods for extreme rainfall estimation under climate change. Atmospheric Research, 103, pp. 119-128. DOI: 10.1016/j.atmosres.2011.06.011

Sutanta, H., Rajabifard, A. \& Bishop, I. D. (2010) Integrating spatial planning and disaster risk reduction at the local level in the context of spatially enabled government. Paper presented at the GSDI 12 Conference, 19-22 October, Singapore. Typescript.

Thompson, M. P., Haas, J. R., Gilbertson-Day, J. W., Scott, J. H., Langowski, P., Bowne, E., et al. (2015) Development and application of a geospatial wildfire exposure and risk calculation tool. Environmental Modelling \& Software, 63, pp. 61-72. DOI: 10.1016/j.envsoft.2014.09.018

Trontelj, M. (1997a) Kronika izrednih vremenskih dogodkov XX. stoletja: pomembni vremenski dogodki v zgodovini; vreme ob pomembnih dogodkih. Ljubljana, Hydrological and Meteorological Service of the Republic of Slovenia.

Trontelj, M. (1997b) Snegolom ob koncu leta 1995 in januarski žled. Ujma, 11, pp. 46-48.

United Nations Framework Convention on Climate Change (2014) Background on the UNFCCC: The international response to climate change. Available at: https://unfccc.int (accessed 29 Mar. 2014).

United Nations Office for Disaster Risk Reduction (2014) Terminology. Available at: http://www.unisdr.org (accessed 2 Mar. 2014).

United States Environmental Protection Agency (2012a) Climate change adaptation plan: Public review draft. Available at: http://epa.gov (accessed 2 Mar. 2014).

United States Environmental Protection Agency (2012b) Risk assessment: Basic information. Available at: http://epa.gov/riskassessment/ basicinformation.htm\#risk (accessed 2 Mar. 2014).

Van Aalst, M. K. (2006) The impacts of climate change on the risk of natural disasters. Disasters, 30(1), pp. 5-18.

DOI: 10.1111/j.1467-9523.2006.00303.x

Wilbanks, T. J., Bhatt, V., Bilello, D. E., Bull, S. R., Eckmann, J., Horak, et al. (2008) Effects of climate change on energy production and use in the
United States. Research report. Washington, DC, Department of Energy, Office of Biological and Environmental Research.

Willems, P., Arnbjerg-Nielsen, K., Olsson, J. \& Nguyen, V. T. V. (2012) Climate change impact assessment on urban rainfall extremes and urban drainage: Methods and shortcomings. Atmospheric Research, 103, pp. 106-118. DOI: 10.1016/j.atmosres.2011.04.003

Wilson, E. (2006) Adapting to climate change at the local level: The spatial planning response. Local Environment, 11(6), pp. 609-625. DOI: 10.1080/13549830600853635

Wilson, E. \& Piper, J. (2010) Spatial planning and climate change. London, Routledge.

Wiser, R. \& Bolinger, M. (2014) 2013 Wind technologies market report. Washington, DC, US Department of Energy. DOI: 10.2172/1220281

Zadnik, B. (1997) Vpliv žledenja na daljnovode. In: Pregl, M. (ed.) Jeklene konstrukcije imajo bodočnost, pp. 197-206. Ljubljana, Institute of Metal Constructions.

Zadnik, B. (2006) Fenomen žleda in njegov vpliv na objekte za prenos električne energije. Ljubljana, University of Ljubljana, Faculty of Civil and Geodetic Engineering.

Zhou, S., Mikkelsen, P. S., Halsnaes, K. \& Arnbjerg-Nielsen, K. (2012) Framework for economic pluvial flood risk assessment considering climate change effects and adaptation benefits. Journal of Hydrology, 414-415, pp. 539-549. DOI: 10.1016/j.jhydrol.2011.11.031 